\title{
The Effect of Transformational Leadership and Integrity on Quality of Work Life Government Internal Supervision Officers Republic of Indonesia Ministry of Law and Human Rights
}

\author{
J Martanto' , S Tippe ${ }^{2}$, B Santoso ${ }^{3}$ \\ \{1 jokomartanto@unj.ac.id, ${ }^{2}$ syarifuddintippe@unj.ac.id, ${ }^{3}$ budisantoso@unj.ac.id $\}$ \\ 1,2,3 Universitas Negeri Jakarta, Jakarta, Indonesia
}

\begin{abstract}
Quality of work life is essential to an office that this article aims to analyze the effect of transformational leadership, and integrity of the quality of work life by using a quantitative approach and survey method. The study sample total 132 Government Internal Supervisory Apparatus random. The results showed that; (1) The direct effect positive of transformational leadership on the quality of work life; (2) The direct effect positive of integrity on the quality of work life; (3) The direct effect positive of transformational leadership on the integrity; (4) there is a positive indirect effect of transformational leadership to the quality of work life with integrity. To improve the quality of work life, need to improve the transformational leadership and integrity.
\end{abstract}

Keywords: Transformational Leadership, Integrity, Quality of Work Life

\section{INTRODUCTION}

An organization needs a balance between the level of intensity of work with well-being. Quality of work life or abbreviated QWL aims to understand human behavior in the workplace and ways to improve the well-being, balance between the productivity of the achievement of organizational goals. QWL related to comfortable working conditions for employees, fun, and employees were involved in various decisions the organization's work.

Seeing the importance of QWL, Alqarni in his research it is said that "low QWL causing dissatisfaction in work, increase employee absenteeism, lack of motivation to work, have a negative moral, lack of productivity, and poor performance of the organization" [1]. As according Singhapakdi et. al, that the "quality of work life as a form of employee satisfaction by fulfilling various needs resources, activities, and increased quality in the workplace" [2]. This is according to the results of research Abdul, and Hassan which says that "as a form of employee satisfaction with various needs through the resources, activities and results that come from participation in the workplace" [3].

The reason researchers conducted a study in Government Internal Supervisory Apparatus of the Ministry of Justice and Human Rights of the Republic of Indonesia because there are some problems that occur. Based on the findings of the study found that the high labor intensity of Government Internal Supervisory Apparatus, a workload that many causes frequent overtime work, this is the condition that causes there are some employees who fall ill. In addition, the 
level of well-being are not balanced between the workloads, longer work and their salary, working conditions are less comfortable because there are several groups of fellow employees of the main groups of senior and junior group were still a few years of working so unhealthy competition.

Another problem that arises is related to leadership. It is based on the pre-study related to leadership, including; several programs that do not fit the implementation time as program Prevent to be held in March 2017 but was finally set up in July 2017 this is due to lack of control of work and lack of job evaluation that is not a culture of professionalism for officials, leaders less motivating to employees in work, lack of appreciating the work of employees, and do not understand the needs of employees due to not build persuasive communication with employees.

Problems also occur on aspects of employee integrity. Based on the results of pre-study found that there are some employees who do not have integrity in their work as in monitoring dishonest because supervised has a close relationship with regulatory authorities, there are also some supervisors when return service from out of town do not go directly to the office when the clock office still exists, dishonest conduct surveillance while in the field, not transparant about the weakness and lack of time to supervise. In this study, there are several variables including the concept of QWL, transformational leadership and integrity.

The term QWL was first introduced in the International Labor Conference in 1972, but only gained attention after the United Auto Workers and General Motors took the initiative to adopt the practice of changing the quality of working life for the working system. There are several definitions of quality of working life including; by Farid that "as an effort to improve the quality of the organization and take advantage of the benefits of an organization. Quality of work life is the center of attention for the employees so that its role can be enhanced and increase their participation in the development of the organization" [4].

Similar feelings were expressed by Khashman et. al, that a work situation or development reflects an increase in all elements of the organization and the basics of the environment to ensure all employees to be able to adapt, and increase the potential of human resources. Human resources play a very important role in the success of the organization [5].

Further on transformational leadership is a topic to attract many people and are defined in many ways. Transformational leadership style is an activity affects the people that they like to achieve goals. According Phaneuf et. al, that a leadership style that is geared towards change and enhanced performance, both individually and or collectively" [6]. Furthermore, according to Pradhan, and Prasad that "transformational leadership can help the employees involved to gain the trust of the organization" [7]. This is in accordance opinions Olcum and Fayda that "transformational leaders change personal values subordinate to support the vision and goals of the organization and establish a climate of trust between leaders and subordinates" [8].

The next variable on integrity, according to Elsetouhi et. al that "integrity is associated with a range of values associated with the construction, morality, honesty, ethical, and sincerity" [9]. While Cheng et.al also says that the "integrity implies that individual behavior is consistent with the values of honesty and trustworthy. At the individual level, the integrity of an ethics, character, honest, ethical, transparent and credible"[10]. This is in accordance opinions Hafiz, M. Azizal, and Mohd that "The integrity of the building within an organization to foster mutual trust between leaders and subordinates" [11].

\section{RESEARCH METHOD}

The method in this research is the survey will be analyzed using path analysis (path analysis). Questionnaires were used to obtain research data consists of three variables, namely: quality of 
work life (Y), transformational leadership (X1), integrity (X2). Inferential analysis using Structural Equation Modeling, or better known as (SEM). This research was conducted at the Government Internal Supervisory Apparatus (APIP) of the Ministry of Justice and Human Rights of the Republic of Indonesia The number of research subjects as many as 132 officers.

\section{RESULTS AND DISCUSSION}

Based on the findings in the field can be described as follows:

First hypothesis, positive direct influence transformational leadership of the QWL. Parameter estimation of testing direct influence transformational leadership on QWL shows the value of CR for 2662 with a probability value of 0.008 . Values above are qualified acceptance of $\mathrm{H}_{1} 2662 \mathrm{CR}$ value is greater than 1.96, and the probability is less than 0.05 . Thus, it can be concluded that the effect on the transformational leadership of the QWL. Then $\mathrm{H}_{0}$ is rejected and $\mathrm{H}_{1}$ accepted, which means that the direct effect of transformational leadership significantly influence QWL. QWL in some studies associated with leadership, effective leadership which will always have an impact by increasing the quality of working life of employees. According to research results Nazem and Entezari that transformational leadership style has a positive effect on the QWL [12]. Meanwhile, according to Kerstin that transformational leadership recommended as the most suitable approach for an organization that aims at improving the quality of working life of employees [13].

Second hypothesis, positive direct influence integrity of the QWL. Testing the integrity of the direct influence of the QWL showed CR values of 2,532 and a probability value of 0011 so it has been eligible for admission $\mathrm{H}_{1} 2532$ amounted $\mathrm{CR}$ value is greater than 1.96, and the probability is less than 0.05 . Based on these data, the integrity of a significant direct effect on the QWL. Integrity maintain high performance standards and conduct meaningful intelligence competencies, education, and training to be able to add value through the quality of working life. This is confirmed by Cetinkanat that the quality of work life is a concept that encompasses a variety of disciplines. The principle of integrity requires the employee to have a personality that is based on the elements of honesty, courage, thoughtful, and responsible for establishing trust as a basis for taking a decision [14]. Furthermore according to Birjandi that integrity can improve the quality of working life of employees [15].

Third hypothesis, positive direct influence transformational leadership of the integrity. Transformational leadership on integrity demonstrate the value of CR for 1419 and with a probability value of 0156 as well as the values do not meet eligible for admission $\mathrm{H}_{1} 1419$ amounted CR value is greater than 1.96, and the probability is less than 0.05 . So that transformational leadership positively have no direct impact on the integrity. While the research results Engelbrecht found that values such as individual moral responsibility, mutual respect, fulfillment, honor, and integrity can affect transformational leadership [16].

Fourth hypothesis, positive direct influence of transformational leadership to QWL through integrity. The influence of transformational leadership on QWL through integrity demonstrate the value of CR for 1417 with a probability value 0156 . The values do not qualify for admission $\mathrm{H}_{1} 1417$ amounted CR value is greater than 1.96 and a smaller probability of 0.05 , which means that no direct influence transformational leadership positively to QWL through integrity. While based on research results Helmiatin that transformational leadership a positive effect on QWL [17] [18]. 


\section{CONCLUSIONS}

Based on the results it can be concluded that research transformational leadership has a positive direct impact significantly on the QWL, integrity positive direct impact significantly on the QWL, transformational leadership significantly positive direct effect on the integrity, and the indirect effect of transformational leadership positively to QWL through integrity.

\section{REFERENCES}

[1] S. A. Y. Alqarni, "Quality of Work Life as a Predictor of Work Engagement among the Teaching Faculty at King Abdulaziz University,” Int. J. Humanit. Soc. Sci., vol. 6, no. 1 , pp. 1-20, 2016.

[2] A. Singhapakdi, D. Lee, M. J. Sirgy, and K. Senasu, "The Impact of Incongruity Between an Organization's CSR Orientation and its Employees ' CSR Orientation on Employees ' Quality of Work Life,’ J. Bus. Res., vol. 22, no. 2, pp. 1-7, 2014.

[3] N. Abdul, H. Ma, and N. Hassan, "Measuring Reliability and Validity Instruments of Work Environment towards Quality Work Life," Procedia Econ. Financ., vol. 37, no. 2, pp. 520-528, 2016.

[4] H. Farid, Z. Izadi, I. A. Ismail, and F. Alipour, "Relationship between Quality of Work Life and Organizational Commitment Among Lecturers in a Malaysian Public Research University,” Soc. Sci. J., vol. 8, no. 1, pp. 1-8, 2014.

[5] A. Khashman, A. Assaf, F. Alzubi, and A. Alsawalhah, "The Main Resources of Diversity and its Effects on the Quality of Work Life of Human Resources," Int. J. Adv. Res., vol. 5, no. 2, pp. 1-15, 2017.

[6] J.-élaine Phaneuf, J. Boudrias, V. Rousseau, and É. Brunelle, "Personality and Transformational Leadership: The Moderating Effect of Organizational Context," PAID, vol. 102, no. 2, pp. 30-35, 2016.

[7] L. Kesari, S. Pradhan, and N. Prasad, "Asia Paci fi c Management Review Pursuit of Organisational Trust: Role of Employee Engagement, Psychological Well-Being and Transformational Leadership," Asia Pacific Manag. Rev., vol. 20, no. 1, pp. 1-8, 2017.

[8] M. Olcum and F. S. Fayda, "An analysis of Academic Leadership Behavior from the Perspective of Transformational Leadership," Procedia - Soc. Behav. Sci., vol. 207, no. 2, pp. 1-9, 2015.

[9] A. M. Elsetouhi, A. A. Hammad, A. A. Nagm, and A. Mohamed, "Perceived Leader Behavioral Integrity and Employee Voice in SMEs Travel Agents : The Mediating Role of Empowering Leader Behaviors," Tour. Manag., vol. 65, no. 1, pp. 100-115, 2018.

[10] C. Cheng, D. Jiang, B. Cheng, J. H. Riley, and C. Jen, "When do Subordinates Commit to their Supervisors? Different Effects of Perceived Supervisor Integrity and Support on Chinese and American Employees,” Leadersh. Q., vol. 23, no. 1, pp. 1-17, 2014.

[11] M. H. Rosli, M. A. bin A. Aziz, F. Mohd, and J. Said, "Integrity Systems in Malaysian Public Sector: An Empirical Finding,” Procedia Econ. Financ., vol. 28, no. 2, pp. 260 265, 2015.

[12] F. Nazem and M. S. Entezari, "Prediction of Employee Quality of Work Life Based on the Leadership Styles (Transformational and Transactional) at the Ministry of Education,” Indian J. Fundam. Appl. Life Sci., vol. 4, no. 1989, pp. 1-5, 2014.

[13] I. H. Kerstin, "Quality of Work Life in the Hospitality Industry," Int. J. Copenhagen Bus. Sch., vol. 23, no. 2, pp. 1-11, 2014.

[14] A. C. Çetinkanat and M. A. Kösterelioğlu, "Relationship between Quality of Work Life 
and Work Alienation: Research on Teachers," Univers. J. Educ. Res., vol. 4, no. 8, pp. $1-9,2016$.

[15] M. Birjandi, "The Relationship between the Quality of Work Life and Organizational Commitment of the Employees of Darab Cement Company : Case study In Iran,” Int. J. Econ. Bus. Financ., vol. 1, no. 7, pp. 1-11, 2013.

[16] A. S. Engelbrecht, "The Relationship between Transformational Leadership, Integrity and an Ethical Climate in Organisations," J. Hum. Resour. Manag., vol. 21, no. 1, pp. $1-10,2015$.

[17] Helmiatin, "The Implementation of Transformational Leadership and Quality of Worklife toward Organizational Citizenship Behavior,” Int. J. Innov. Manag. Technol., vol. 5, no. 5, pp. 1-5, 2014.

[18] K. Saddhono, "Language of Coastal Communities in the Northern Coast of Central Java: Sociolinguistic Studies in Cultural Integration Maritime-Agrarian Perspective." Adv. Sci. Let. vol. 23 no. 10 pp 10054-10056, 2017 